Article

\title{
A $\beta$-cyclodextrin Modified Graphitic Carbon Nitride with Au Co-Catalyst for Efficient Photocatalytic Hydrogen Peroxide Production
}

\author{
Guifu Zuo ${ }^{1}$, Yuqian Zhang ${ }^{1}$, Shanshan Liu ${ }^{2}$, Zhaoliang Guo ${ }^{1}$, Qiannan Zhao ${ }^{1}$, \\ Gopalan Saianand ${ }^{3}{ }^{\circledR}$, Liwei Feng ${ }^{1}$, Lijuan Li ${ }^{1}$, Wangze Li ${ }^{1}$, Ning Zhang ${ }^{4}$, \\ Xianguang Meng ${ }^{1,5, *}$ and Vellaisamy A. L. Roy ${ }^{6, *}$ (i) \\ 1 Hebei Provincial Laboratory of Inorganic Nonmetallic Materials, College of Materials Science and \\ Engineering, North China University of Science and Technology, Tangshan 063210, China; \\ zuoguifu@163.com (G.Z.); 18332737639@163.com (Y.Z.); guozhaoliangcl@163.com (Z.G.); \\ 18332725160@163.com (Q.Z.); 13473519550@163.com (L.F.); Lilj5527@163.com (L.L.); \\ Liwangze2008@126.com (W.L.) \\ 2 College of Materials Science and Engineering, Zhengzhou University, Zhengzhou 450001, China; \\ 18712839227@163.com \\ 3 Global Centre for Environmental Remediation (GCER), Faculty of Science, The University of Newcastle, \\ Callaghan, NSW 2308, Australia; saianand.gopalan@gmail.com \\ 4 School of Materials Science and Engineering, Central South University, Changsha 410083, China; \\ nzhang@csu.edu.cn \\ 5 Department of Materials Science and Engineering, City University of Hong Kong, Tat Chee Avenue, \\ Kowloon, Hong Kong 999077, China \\ 6 James Watt School of Engineering, University of Glasgow, Glasgow G12 8QQ, UK \\ * Correspondence: mengxg_materchem@163.com (X.M.); Roy.Vellaisamy@glasgow.ac.uk (V.A.L.R.)
}

Received: 2 September 2020; Accepted: 16 September 2020; Published: 4 October 2020

\begin{abstract}
Photocatalytic hydrogen peroxide $\left(\mathrm{H}_{2} \mathrm{O}_{2}\right)$ production has attracted considerable attention as a renewable and environment-friendly method to replace other traditional production techniques. The performance of $\mathrm{H}_{2} \mathrm{O}_{2}$ production remains limited by the inertness of graphitic carbon nitride $(\mathrm{CN})$ towards the adsorption and activation of $\mathrm{O}_{2}$. In this work, a photocatalyst comprising of $\beta$-cyclodextrin $(\beta-C D)$-modified $\mathrm{CN}$ with supporting Au co-catalyst ( $\mathrm{Au} / \beta-\mathrm{CD}-\mathrm{CN})$ has been utilized for effective $\mathrm{H}_{2} \mathrm{O}_{2}$ production under visible light irradiation. The static contact angle measurement suggested that $\beta-C D$ modification increased the hydrophobicity of the $\mathrm{CN}$ photocatalyst as well as its affinity to oxygen gas, leading to an increase in $\mathrm{H}_{2} \mathrm{O}_{2}$ production. The rate of $\mathrm{H}_{2} \mathrm{O}_{2}$ production reached more than $0.1 \mathrm{mM} / \mathrm{h}$ under visible-light irradiation. The electron spin resonance spectra indicated that $\mathrm{H}_{2} \mathrm{O}_{2}$ was directly formed via a 2-electron oxygen reduction reaction (ORR) over the $\mathrm{Au} / \mathrm{\beta}-\mathrm{CD}-\mathrm{CN}$ photocatalyst.
\end{abstract}

Keywords: photocatalysis; oxygen reduction reaction; hydrogen peroxide; graphitic carbon nitride; $\beta$-cyclodextrin

\section{Introduction}

Hydrogen peroxide $\left(\mathrm{H}_{2} \mathrm{O}_{2}\right)$, is not only an oxidant but also an important product and/or a by-product in chemical and environmental protection [1-5]. At present, the anthraquinone method for industrial $\mathrm{H}_{2} \mathrm{O}_{2}$ production requires massive energy and organic solvents [6]. Compared with the anthraquinone method, the photocatalytic $\mathrm{H}_{2} \mathrm{O}_{2}$ production over semiconductors, such as $\mathrm{TiO}_{2}[7,8], \mathrm{ZnO}[9,10], \mathrm{BiVO}_{4}[11,12]$, and carbon nitride (CN) [13-17] is an ideal pathway that only uses solar light as driving force. In particular, metal-free $\mathrm{CN}$ has attracted great attention due 
to its visible light-responsive, environmentally friendly, and easy-synthesis features [18]. However, the photocatalytic activity of pure $\mathrm{CN}$ is still limited due to the recombination of charge carriers and poor activation ability of $\mathrm{O}_{2}$ for producing $\mathrm{H}_{2} \mathrm{O}_{2}$. An important strategy is loading proper co-catalyst on the surface of a photocatalyst to promote the charge separation and the activation of $\mathrm{O}_{2}[19,20]$. Our previous study found that finely dispersed $\mathrm{Au}$ nanoparticles were excellent co-catalysts for improving the photocatalytic activity of $\mathrm{CN}$ toward enhancing the production of $\mathrm{H}_{2} \mathrm{O}_{2}$ [21]. The Au/CN system provided a promising prototype for producing concentrated $\mathrm{H}_{2} \mathrm{O}_{2}$ with an extremely low Au loading amount. In the liquid reaction system, the $\mathrm{H}_{2} \mathrm{O}_{2}$ production is limited by the adsorption of oxygen gas on photocatalyst because of the low solubility of oxygen gas in water and the inert surface nature of CN. Recently, we found a new method to further improve the performance of $\mathrm{Au} / \mathrm{CN}$ for photocatalytic $\mathrm{H}_{2} \mathrm{O}_{2}$ synthesis by the modification of $\beta$-cyclodextrin $(\beta-\mathrm{CD})$ on $\mathrm{CN}(\beta-\mathrm{CD}-\mathrm{CN})$. The $\beta-\mathrm{CD}$ is a cyclic oligosaccharide with abundant oxygen-containing functional groups with a ring structure.Interestingly, the $\beta-C D$ could significantly improve the hydrophobicity as well as oxygen adsorption of $\mathrm{CN}$. Thus $\mathrm{H}_{2} \mathrm{O}_{2}$ production rate of $\mathrm{Au} / \beta-\mathrm{CD}-\mathrm{CN}$ under visible light irradiation was much higher than $\mathrm{Au} / \mathrm{CN}$. Simultaneously, the $\mathrm{Au} / \beta-\mathrm{CD}-\mathrm{CN}$ hybrid was very inert to catalyze the decomposition of $\mathrm{H}_{2} \mathrm{O}_{2}$, which was beneficial to the production of concentrated $\mathrm{H}_{2} \mathrm{O}_{2}$.

\section{Materials and Methods}

\subsection{Preparation of Photocatalysts}

\subsubsection{Preparation of $\mathrm{g}-\mathrm{C}_{3} \mathrm{~N}_{4}$}

The $\mathrm{g}-\mathrm{C}_{3} \mathrm{~N}_{4}$ was prepared according to a reported procedure [22]. Dicyandiamide (Yongda Chemical Reagent Co., Ltd, Tianjin, China) was kept on a covered crucible and heated at a ramping rate of $3{ }^{\circ} \mathrm{C} / \mathrm{min}$ up to $550{ }^{\circ} \mathrm{C}$ for $4 \mathrm{~h}$ in the air.

\subsubsection{Preparation of $\beta-C y c l o d e x t r i n-C a r b o n$ Nitride $(\beta-C D-C N)$ Composite}

Typically, $12 \mathrm{~g}$ of $\beta$-CD (Yongda Chemical Reagent Co., Ltd, Tianjin, China) and $0.4228 \mathrm{~g}$ of $\mathrm{NaOH}$ (Yongda Chemical Reagent Co., Ltd, Tianjin, China) were mixed in $100 \mathrm{~mL}$ of water under vigorous stirring at $90{ }^{\circ} \mathrm{C}$ to remove the residual water. Then, the precipitate was ground into a fine powder. $8 \mathrm{~g}$ of treated $\beta$-CD was completely dissolved in N,N-Dimethylformamide (DMF) (Yongda Chemical Reagent Co., Ltd, Tianjin, China) at $90^{\circ} \mathrm{C}$. $1.5 \mathrm{~mL}$ of $\gamma$-(2,3-epoxypropoxy) propyl trimethoxysilane (KH-560) (Guangfu Fine Chemical Research Institute, Tianjin, China) was continuously added and stirred for $6 \mathrm{~h}$. Then, $4 \mathrm{~g}$ of $\mathrm{CN}$ was put into the above solution and stirred for $12 \mathrm{~h}$. The sample was thoroughly washed with distilled water and dried at $80^{\circ} \mathrm{C}$ for $12 \mathrm{~h}$.

\subsubsection{Preparation of Metal Co-Catalyst/ $\beta-C D-C N$ Nanocomposite}

$\mathrm{HAuCl}_{4} \cdot 4 \mathrm{H}_{2} \mathrm{O}$ (Guangfu Fine Chemical Research Institute, Tianjin, China) $(335.8 \mu \mathrm{L}, 0.0243 \mathrm{~mol} / \mathrm{L})$ was added to $250 \mathrm{~mL}$ of water containing $\beta-\mathrm{CD}-\mathrm{CN}(2.5 \mathrm{~g})$. The water was volatilized at $70{ }^{\circ} \mathrm{C}$ under vigorous stirring. The obtained sample reacted with $\mathrm{KBH}_{4}$ (Guangfu Fine Chemical Research Institute, Tianjin, China) to reduce $\mathrm{HAuCl}_{4} \cdot 4 \mathrm{H}_{2} \mathrm{O}$ under vigorous stirring for $3 \mathrm{~h}$. Then, the sample was centrifuged and washed with distilled water. The sample was designated as $0.05 \% \mathrm{Au} / \beta-\mathrm{CD}-\mathrm{CN}$. Accordingly, $0.03 \%, 0.08 \%$, and $0.1 \% \mathrm{Au} / \beta-\mathrm{CD}-\mathrm{CN}$ were obtained by the same procedure. For a fair comparison, $0.05 \% \mathrm{Pt} / \beta-\mathrm{CD}-\mathrm{CN}, \mathrm{Ag} / \beta-\mathrm{CD}-\mathrm{CN}$, and $\mathrm{Pd} / \beta-\mathrm{CD}-\mathrm{CN}$ were prepared as above using $\mathrm{H}_{2} \mathrm{PtCl}_{6} \cdot 6 \mathrm{H}_{2} \mathrm{O}, \mathrm{AgNO}_{3}$, and $\mathrm{PdCl}_{2}$ (Guangfu Fine Chemical Research Institute, Tianjin, China), respectively.

\subsection{Material Characterization}

X-ray diffraction (XRD) data were obtained on an X-ray diffractometer (Rigaku SmartLab, Tokyo, Japan) operating with $\mathrm{Cu} \mathrm{K} \alpha$ radiation. Energy-dispersive spectroscopy (EDS) was recorded by a 
scanning electron microscope (SEM) (FEI Scios, OR, USA) to analyze the elemental compositions of $\mathrm{Au} / \beta-\mathrm{CD}-\mathrm{CN}$. TEM observations were performed using a scanning transmission electron microscope (STEM) (JEOL JEM-ARM200F, Tokyo, Japan) operated at 200 kV.Ultraviolet-visible (UV-vis) spectra were collected by Lambda 750S UV-vis spectrometer (Perkin-Elmer, Waltham, MA, USA) with an integrating sphere scanning from 300 to $600 \mathrm{~nm}$. Photoluminescence spectra were obtained with a fluorescence spectrometer (PerkinElmer LS55, Waltham, MA, USA). The static contact angle (water) was tested with the contact angle system ((DH-HV1351UM, Shanghai Zhongchen Digital Technology Equipment Co., Ltd., Shanghai, China).

\subsection{Photocatalytic Reactivity Test and $\mathrm{H}_{2} \mathrm{O}_{2}$ Decomposition}

Typically, photocatalyst $(0.4 \mathrm{~g})$ was put into $100 \mathrm{~mL}$ of an aqueous solution including $10 \mathrm{~mL}$ of $\mathrm{C}_{2} \mathrm{H}_{5} \mathrm{OH}$ (sacrificial agent) to evaluate $\mathrm{H}_{2} \mathrm{O}_{2}$ production according to the literature [21]. The system was ultrasonicated for $3 \mathrm{~min}$. The temperature of the reaction solution was cooled by the flow of cooling water which keep the system at room temperature. A $300 \mathrm{~W}$ Xe visible lamp with a UVCUT420 filter $(\lambda>420 \mathrm{~nm})$ (PLS-SXE300, Bofeilai Technology Co., Ltd, Beijing, China) was used as visible light source with a constant flow of $\mathrm{O}_{2}$. The generated $\mathrm{H}_{2} \mathrm{O}_{2}$ was measured by a spectrophotometric method, using 2,9-dimethyl-1,10-phenanthroline (DMP) (Wengjiang Chemical Reagent Co., Ltd, Guangdong, China) and copper (II) ion (Guangfu Fine Chemical Research Institute, Tianjin, China) [23].

The decomposition test of $\mathrm{H}_{2} \mathrm{O}_{2}$ was similar to $\mathrm{H}_{2} \mathrm{O}_{2}$ production. The photocatalyst $(0.4 \mathrm{~g})$ and aqueous solution (ethanol:water $=1: 9$ ) were mixed in the reaction cell with $\mathrm{H}_{2} \mathrm{O}_{2}$ (Yongda Chemical Reagent Co., Ltd, Tianjin, China) $(3500 \mu \mathrm{M})$. A $300 \mathrm{~W}$ Xe visible lamp was chosen as an irradiation source with a constant flow of $\mathrm{N}_{2}$ supply.

\subsection{Electron Spin Resonance (ESR) Test}

Electron spin resonance (ESR) analysis with 5,5-dimethyl-1-pyrroline N-oxide (DMPO) (Wengjiang Chemical Reagent Co., Ltd, Guangdong, China) as a spin-trapping reagent was performed to confirm the pathway of $\mathrm{O}_{2}$ reduction over different catalysts. ESR signals of radicals trapped by DMPO were detected with a ESP 300E spectrometer (Brucker, Faellanden, Switzerland). Typically, catalyst $(20 \mathrm{mg})$ was added to an alcohol/water mixture $(1 / 9 v / v, 5 \mathrm{~mL})$ containing DMPO $(0.125 \mathrm{mmol})$ within a container. After $\mathrm{O}_{2}$ bubbling for $3 \mathrm{~min}$, the container was photo irradiated for $5 \mathrm{~min}$. The catalyst was recovered by filtration, and the solution was subjected to analysis at room temperature.

\section{Results and Discussion}

\subsection{Material Characterization}

\subsubsection{Surface Morphology Characterization}

The SEM image shows that the as-developed $(0.05 \% \mathrm{Au} / \beta-\mathrm{CD}-\mathrm{CN})$ has an irregular layer structure (Figure 1a). The EDS result in Figure $1 \mathrm{~b}$ demonstrates the co-existence of $\mathrm{C}, \mathrm{N}, \mathrm{O}$, and $\mathrm{Au}$ atoms over the $\mathrm{Au} / \beta-\mathrm{CD}-\mathrm{CN}$. The $\mathrm{O}$ atom shown in EDS is attributed to the $\beta-\mathrm{CD}$. The actual Au content of $0.03 \%$, $0.05 \%, 0.08 \%$, and $0.1 \% \mathrm{Au} / \beta-\mathrm{CD}-\mathrm{CN}$ samples were found to be $0.013 \%, 0.047 \%, 0.085 \%$, and $0.106 \%$ through inductively coupled plasma mass spectrometry (ICP-MS) (Table S1). 

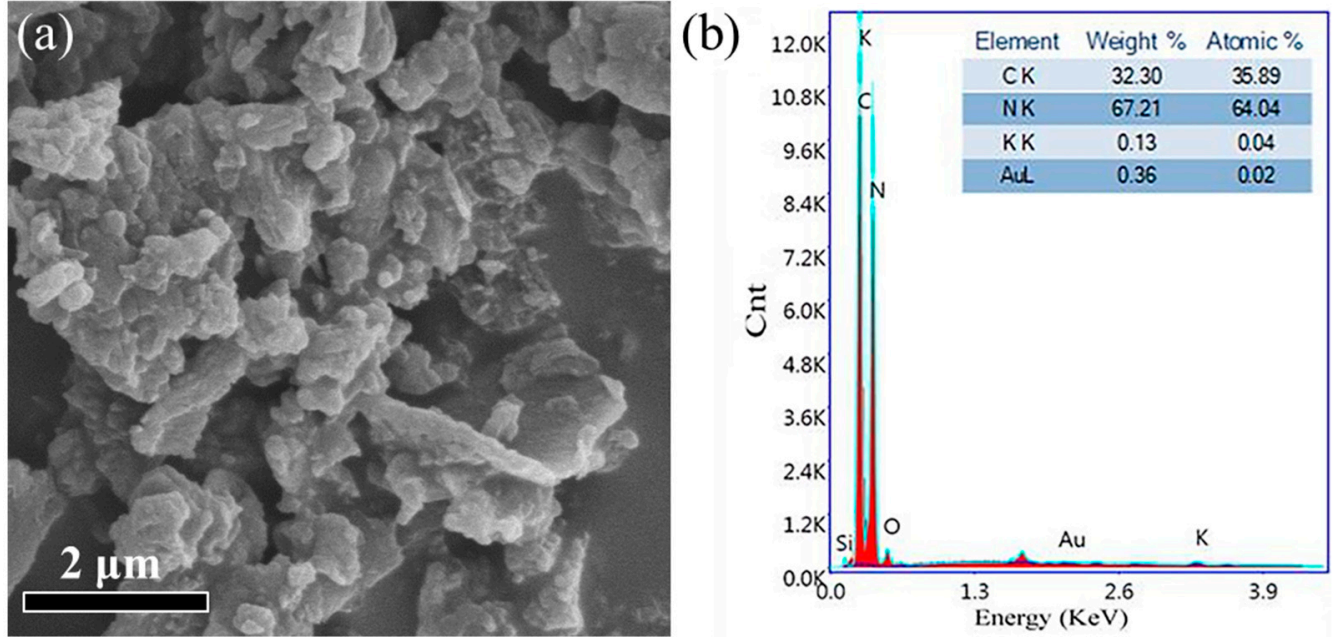

Figure 1. (a) Scanning electron microscopy (SEM) image of $0.05 \% \mathrm{Au} / \beta$-cyclodextrin-carbon nitride $(\beta-\mathrm{CD}-\mathrm{CN})$; (b) energy-dispersive spectroscopy (EDS) spectra of $0.05 \% \mathrm{Au} / \beta-\mathrm{CD}-\mathrm{CN}$.

The STEM images (high resolution and low resolution) of $0.05 \% \mathrm{Au} / \mathrm{\beta}-\mathrm{CD}-\mathrm{CN}$ are shown in Figure 2. It can be found that $\mathrm{Au}$ particles are finely dispersed on the surface of $\beta-\mathrm{CD}-\mathrm{CN}$. The average size of Au nanoparticles is about $3 \mathrm{~nm}$ in diameters.

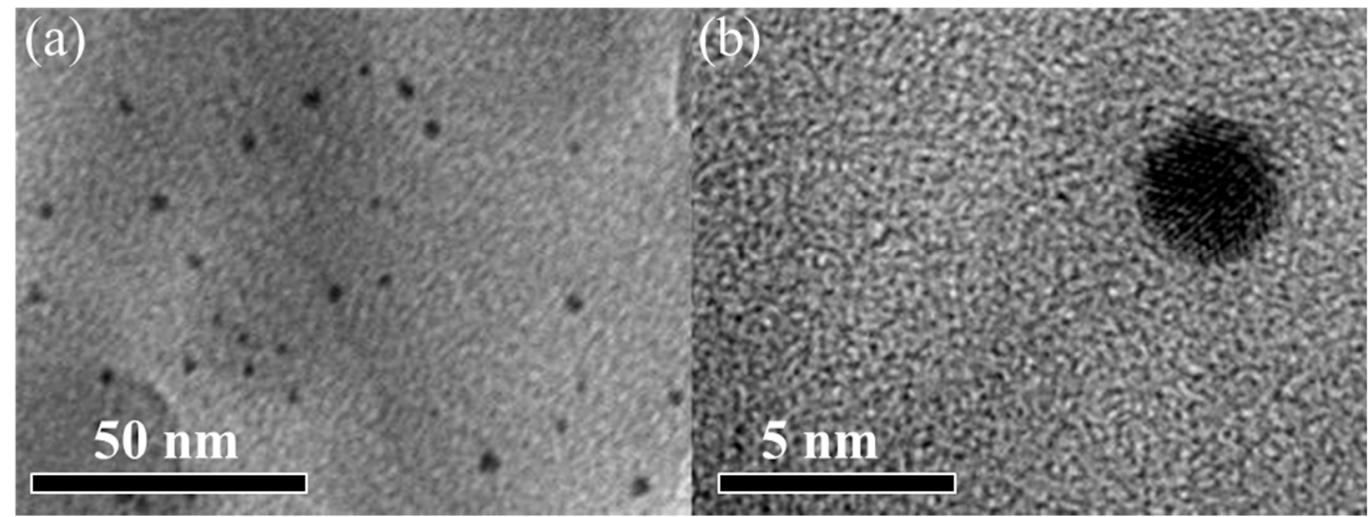

Figure 2. (a) Low and (b) high magnification STEM image of $0.05 \% \mathrm{Au} / \beta-\mathrm{CD}-\mathrm{CN}$.

\subsubsection{X-Ray Diffraction (XRD) and Fourier Transform Infrared (FT-IR) Characterizations}

All investigated samples show X-ray diffraction (XRD) patterns which can be obviously seen at $12.8^{\circ}$ and $27.4^{\circ}$, indicating that they all have a similar crystal structure to $\mathrm{CN}$ (Figure 3a) [22]. The peak at $12.8^{\circ}$ is related to the crystal plane of (100), which is attributed to the existence of an oxazine ring network. The peak at $27.4^{\circ}$ corresponds to the characteristic interlayer stacking reflection of conjugated aromatic systems. As for $\mathrm{Au}$, its content is relatively low, thus its diffraction peaks cannot be observed directly $[24,25]$.

Figure $3 \mathrm{~b}$ shows the Fourier transform infrared (FT-IR) spectra of the as-prepared CN, $\beta-C D-C N$, and $\beta-C D$. The original $C N$ shows typical characteristic peaks as reported [26]. The peak at $810 \mathrm{~cm}^{-1}$ can be correlated to the vibrational absorptions of tri-s-triazine subunits. The typical absorption peaks of $\mathrm{CN}$ at $1570 \mathrm{~cm}^{-1}$ and $1635 \mathrm{~cm}^{-1}$ correspond to $\mathrm{C}-\mathrm{N}$ and $\mathrm{C}=\mathrm{N}$, respectively. The vibration bands at $1236 \mathrm{~cm}^{-1}, 1316 \mathrm{~cm}^{-1}$, and $1403 \mathrm{~cm}^{-1}$ belong to the aromatic $\mathrm{C}-\mathrm{N}$ heterocycles. The formation of a broad peak at $3173 \mathrm{~cm}^{-1}$ is linked to $\mathrm{N}-\mathrm{H}$ stretching. All the above peaks arise in the $\beta-\mathrm{CD}-\mathrm{CN}$. After CN modification by $\beta-C D$, new adsorption bands at around $550 \mathrm{~cm}^{-1}, 1027 \mathrm{~cm}^{-1}$, and $1157 \mathrm{~cm}^{-1}$ are related to the $\beta$-phase formation, $\mathrm{C}-\mathrm{O}-\mathrm{C}$, and $\mathrm{C}-\mathrm{C} / \mathrm{C}-\mathrm{O}$. Those are attributed to a large number of hydroxyl groups of $\beta-\mathrm{CD}$ [27-29]. Due to the asymmetric stretching vibration of $\mathrm{C}-\mathrm{H}$, an absorption 
peak appears at $2925 \mathrm{~cm}^{-1}$. The broad vibration band at $3392 \mathrm{~cm}^{-1}$ belongs to $\mathrm{O}-\mathrm{H}$ stretching vibration, which also arises in the spectra of the pure $\beta-C D$ sample. These results clearly indicate the formation of $\beta-\mathrm{CD}-\mathrm{CN}[30]$.
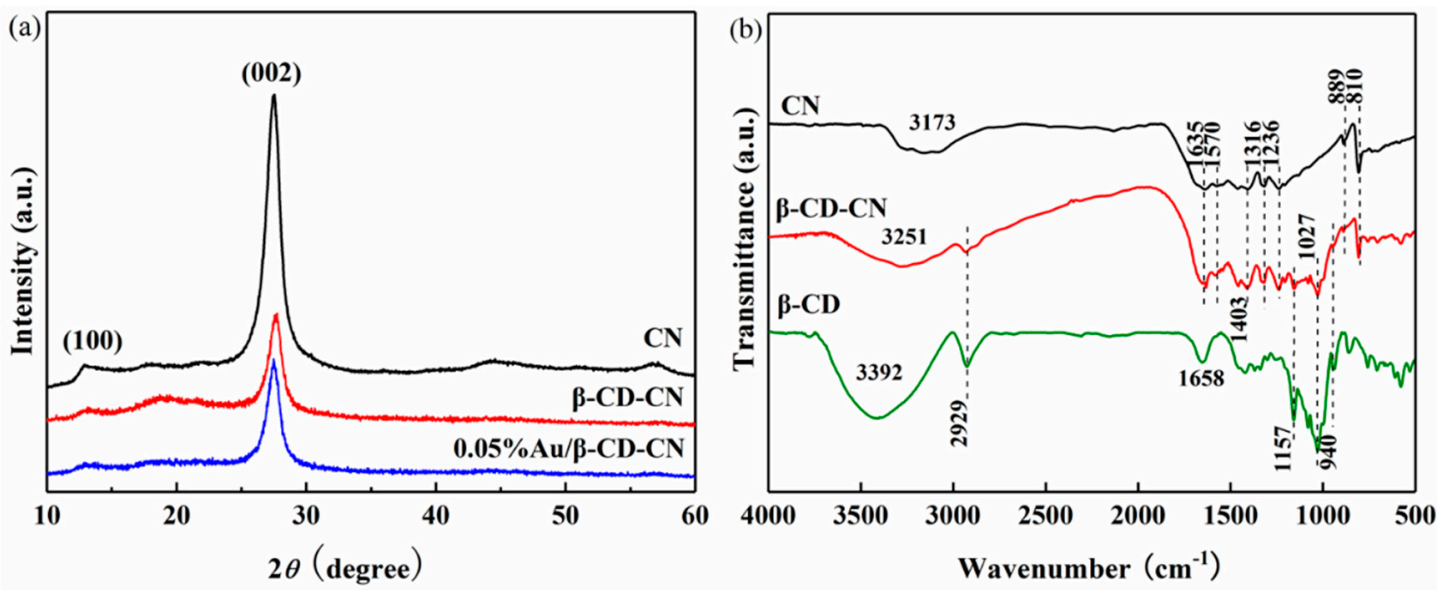

Figure 3. (a) X-ray diffraction (XRD) patterns of $C N, \beta-C D-C N$, and $0.05 \% \mathrm{Au} / \beta-\mathrm{CD}-\mathrm{CN}$; (b) Fourier transform infrared (FT-IR) spectra of $\mathrm{CN}, \beta-\mathrm{CD}-\mathrm{CN}$, and $\beta-\mathrm{CD}$.

\subsubsection{The Optical Absorption, Photoluminescence and Surface Properties}

The optical absorption of $\mathrm{CN}, \beta-\mathrm{CD}-\mathrm{CN}$, and $0.05 \% \mathrm{Au} / \beta-\mathrm{CD}-\mathrm{CN}$ were measured by UV-vis. All samples show wide absorption in the visible region (Figure $4 \mathrm{a}$ ). The absorption edge of $\beta-C D-C N$ is slightly shifted to shorter wavelengths due to the formation of a hydrogen bond between the amino group of $\mathrm{CN}$ and the hydroxyl group of $\beta-\mathrm{CD}$. The hydrogen bond can improve charge separation kinetics and promote photocatalytic efficiency [31]. Compared with the $\beta-C D-C N$, a wide absorption in the range of $375-450 \mathrm{~nm}$ can be observed for $\mathrm{Au} / \beta-\mathrm{CD}-\mathrm{CN}$, which is caused by the surface plasmon effect of $\mathrm{Au}$ in $\beta-\mathrm{CD}-\mathrm{CN}[20,32,33]$.
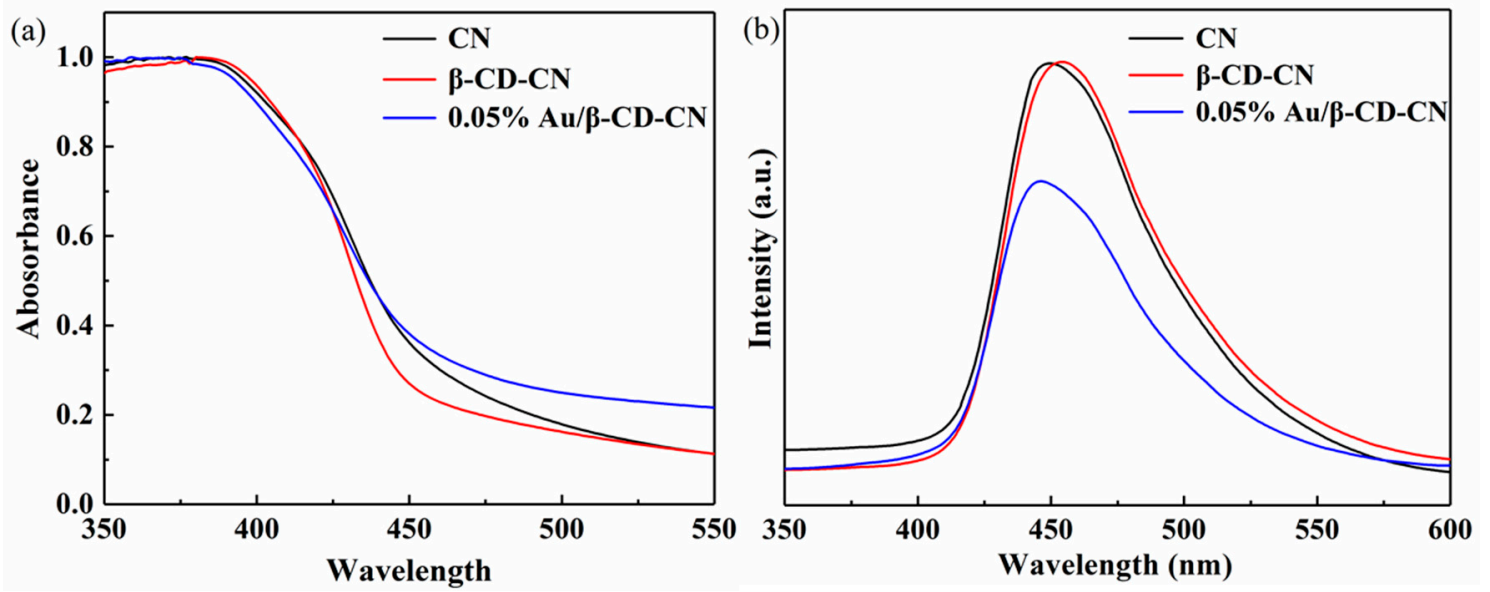

Figure 4. (a) Ultraviolet-visible (UV-vis) diffuse-reflectance spectra and (b) photoluminescence (PL) spectra of $\mathrm{CN}, \beta-\mathrm{CD}-\mathrm{CN}$, and $0.05 \% \mathrm{Au} / \beta-\mathrm{CD}-\mathrm{CN}$.

The photoluminescence (PL) spectra of $\mathrm{CN}, \beta-\mathrm{CD}-\mathrm{CN}$, and $0.05 \% \mathrm{Au} / \beta-\mathrm{CD}-\mathrm{CN}$ nanocomposites are presented in Figure $4 \mathrm{~b}$. The emission peak at $455 \mathrm{~nm}$ is related to the band-band PL phenomenon of $\mathrm{CN}$ [34]. Compared with $\mathrm{CN}$ and $\beta-\mathrm{CD}-\mathrm{CN}$, the PL intensity of $0.05 \% \mathrm{Au} / \beta-\mathrm{CD}-\mathrm{CN}$ is significantly reduced. It is well documented [35] that the PL intensity can be used to characterize the recombination of photogenerated electron-hole pairs. The obvious fluorescence quenching of $0.05 \% \mathrm{Au} / \beta-\mathrm{CD}-\mathrm{CN}$ 
is owing to the efficient separation of charge carriers which is beneficial for increasing $\mathrm{H}_{2} \mathrm{O}_{2}$ production [36].

A water contact angle test was carried out to study the change in the $A u / \beta-C D-C N$ surface property. As shown in Figure 5, it is obvious that the $\beta-C D$ modified $C N$ has a hydrophobic surface with a contact angle of about $89.0^{\circ}$, leading to better adsorption ability to oxygen and thus improved photocatalytic activity of $\mathrm{H}_{2} \mathrm{O}_{2}$ production [37].

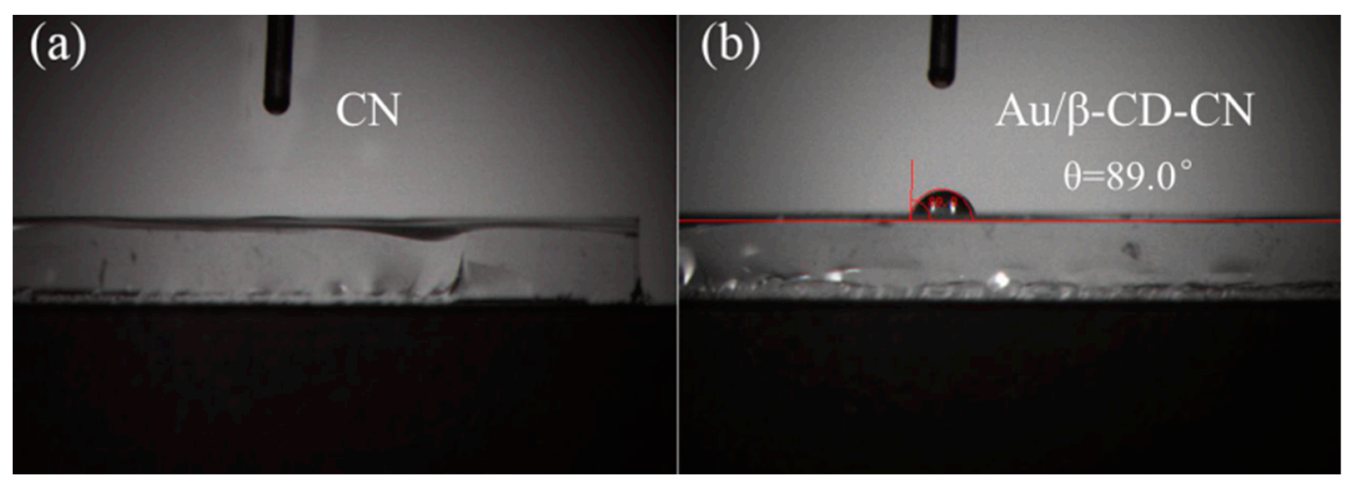

Figure 5. The water contact angle of $\mathrm{CN}(\mathbf{a})$ and $\mathrm{Au} / \beta-\mathrm{CD}-\mathrm{CN}(\mathbf{b})$.

\subsection{Photocatalytic Performance}

\subsubsection{Photocatalytic $\mathrm{H}_{2} \mathrm{O}_{2}$ Production Activity}

The photocatalytic activity of $\mathrm{H}_{2} \mathrm{O}_{2}$ production over $\mathrm{M} / \beta-\mathrm{CD}-\mathrm{CN}$ composite was tested under visible light and a spectrophotometric method was used to quantify the $\mathrm{H}_{2} \mathrm{O}_{2}$ concentrations [37]. The standard curve indicated that the concentration of $\mathrm{H}_{2} \mathrm{O}_{2}$ and absorbance exhibited a good linear relationship with R-square of 0.9988 (Figure S1). The photocatalytic activity of $\beta$-CD-CN with different co-catalysts for $\mathrm{H}_{2} \mathrm{O}_{2}$ production was as follows (Figure 6). The $\beta$-CD modified $\mathrm{CN}$ exhibited excellent photocatalytic activity than $\mathrm{CN}$ for $\mathrm{H}_{2} \mathrm{O}_{2}$ production. Furthermore, the $\mathrm{Au}$ and Ag enhanced photocatalytic activity remarkably for $\mathrm{H}_{2} \mathrm{O}_{2}$ production. $\beta-\mathrm{CD}-\mathrm{CN}$ with $\mathrm{Au}$ loading amount $(0.05 \%)$ showed the best photocatalytic activity for $\mathrm{H}_{2} \mathrm{O}_{2}$ production and the reaction rate reached more than $0.1 \mathrm{mM} / \mathrm{h}$. Moreover, the amount of Au loading on $\beta-\mathrm{CD}-\mathrm{CN}$ is critical to the photocatalytic activity (Figure $6 \mathrm{~b}$ ). When the amount of Au loading exceeds $0.05 \%$ on $\beta-\mathrm{CD}-\mathrm{CN}$, the photocatalytic activity decreased. The high load of Au possibly hindered the light absorption capability of $\mathrm{CN}$ and hence results in decreased photocatalytic activity [38].
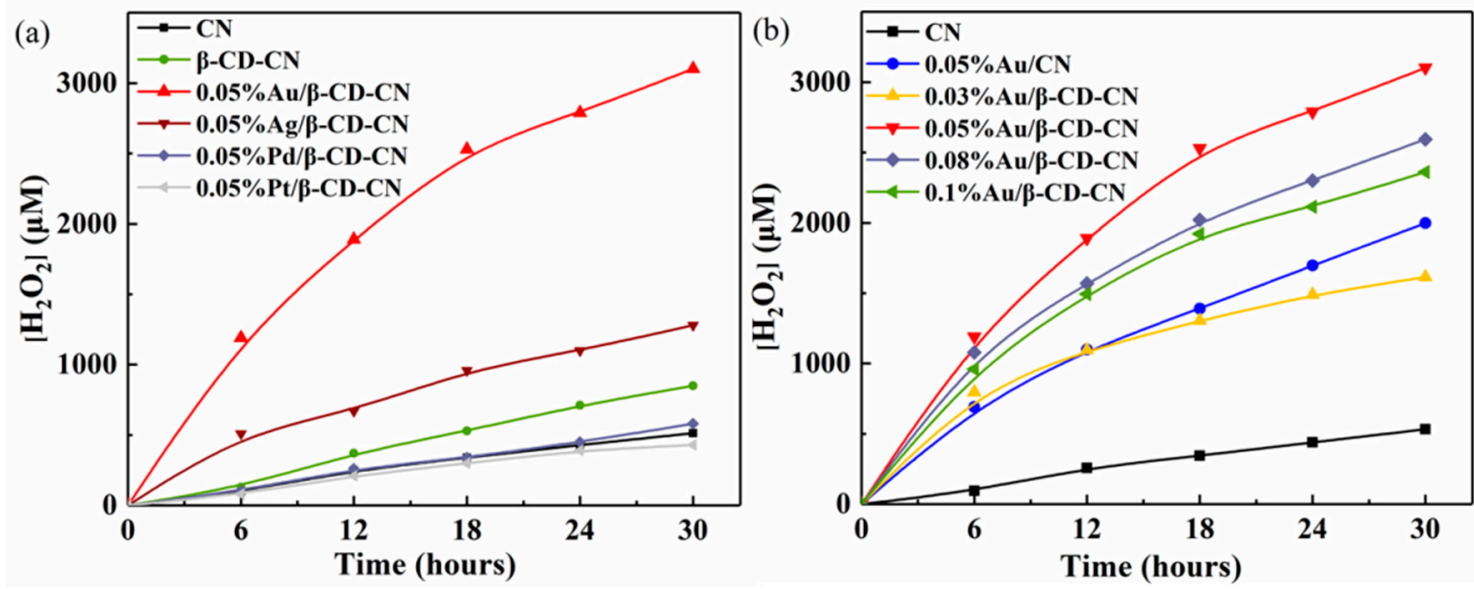

Figure 6. (a) Photocatalytic $\mathrm{H}_{2} \mathrm{O}_{2}$ production over different co-catalysts loaded $\mathrm{CN}$ and (b) $\mathrm{Au} / \beta-\mathrm{CD}-\mathrm{CN}$ with different loading amounts of $\mathrm{Au}(\lambda>420 \mathrm{~nm})$. 


\subsubsection{Photocatalytic $\mathrm{H}_{2} \mathrm{O}_{2}$ Decomposition Activity}

The $\mathrm{H}_{2} \mathrm{O}_{2}$ formation is generally accompanied by $\mathrm{H}_{2} \mathrm{O}_{2}$ decomposition which results in lower $\mathrm{H}_{2} \mathrm{O}_{2}$ production $[6,13]$. Therefore, it is crucial to restrain the decomposition process to keep $\mathrm{H}_{2} \mathrm{O}_{2}$ evolution as sustainable as possible. The results of $\mathrm{H}_{2} \mathrm{O}_{2}$ photodecomposition in aqueous suspension with different photocatalysts are shown in Figure 7. The $\mathrm{Au} / \beta-\mathrm{CD}-\mathrm{CN}$ is inert for the decomposition of $\mathrm{H}_{2} \mathrm{O}_{2}$, which is also the reason for its high $\mathrm{H}_{2} \mathrm{O}_{2}$ production activity. However, the $\mathrm{Pt} / \beta-\mathrm{CD}-\mathrm{CN}$ promotes $\mathrm{H}_{2} \mathrm{O}_{2}$ decomposition via dissociative adsorption and results in a high decomposition rate [39]. Apparently, the $\mathrm{H}_{2} \mathrm{O}_{2}$ decomposition curves of the Au-loaded sample displayed a slow zero-order kinetic process, while the Pt-loaded sample displayed a fast first-order kinetic process.

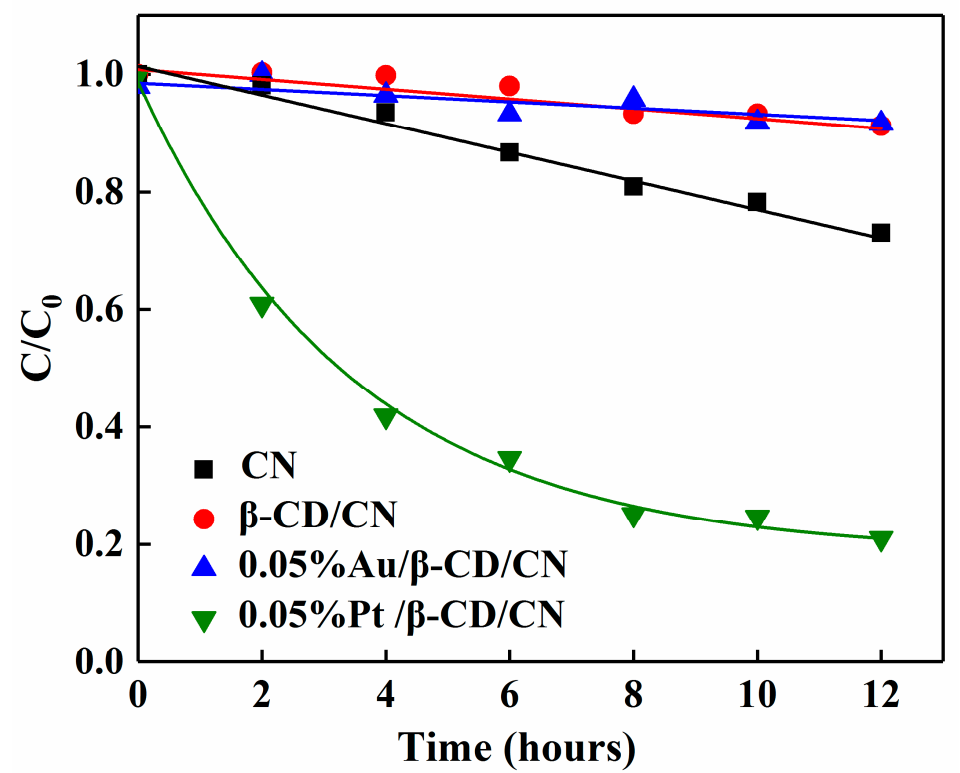

Figure 7. Photodecomposition of $\mathrm{H}_{2} \mathrm{O}_{2}$ in an aqueous $\mathrm{CN}$ suspension with a different metal co-catalyst.

\subsection{Plausible Mechanism of Photocatalysis}

To study the reaction mechanism of $\mathrm{H}_{2} \mathrm{O}_{2}$ production over the photocatalysts, the ESR analysis results are shown in Figure 8. It can be seen that neither the $\cdot \mathrm{OOH}$ signal nor the $\cdot \mathrm{OH}$ signal was observed in the process of $\mathrm{H}_{2} \mathrm{O}_{2}$ production, indicating that $\mathrm{H}_{2} \mathrm{O}_{2}$ was formed via direct 2-electron oxygen reduction over photocatalysis [40].

The mechanism of $\mathrm{Au} / \beta-C D-C N$ photocatalytic activity of $\mathrm{H}_{2} \mathrm{O}_{2}$ is shown in Figure 9. When irradiated by visible light, electrons $\left(\mathrm{e}^{-}\right)$and holes $\left(\mathrm{h}^{+}\right)$are separated (Equation (1)), $\mathrm{e}^{-}$is positioned at the $\mathrm{C} 1$ and $\mathrm{N} 4$ positions of the triazine ring, and $\mathrm{h}^{+}$is positioned at the $\mathrm{N} 2$ and $\mathrm{N} 6$ positions, that is, an electron $\left(\mathrm{e}^{-}\right)$-hole $\left(\mathrm{h}^{+}\right)$pair is formed. However, electrons easily recombine with holes. After $\mathrm{CN}$ is loaded with $\mathrm{Au}$, electrons $\left(\mathrm{e}^{-}\right)$can be rapidly transferred from $\mathrm{C} 1$ and $\mathrm{N} 4$ to $\mathrm{Au}$, thereby effectively inhibiting the recombination of electrons and holes. Holes $\left(\mathrm{h}^{+}\right)$capture $\alpha-\mathrm{H}$ and $\beta-\mathrm{H}$ in $\mathrm{CH}_{3} \mathrm{CH}_{2} \mathrm{OH}$, and $\mathrm{CH}_{3} \mathrm{CH}_{2} \mathrm{OH}$ generates $\mathrm{CH}_{3} \mathrm{CHO}$ (Equation (2)). Immediately after $\beta-\mathrm{CD}$ modification, a hydrogen bond formed between the amino group of $\mathrm{CN}$ and the hydroxyl group of $\beta$-CD. The $\beta$-CD-CN plays an excellent adsorption role with oxygen. Electrons $\left(\mathrm{e}^{-}\right)$reduce $\mathrm{O}_{2}$ to produce $\mathrm{H}_{2} \mathrm{O}_{2}$ and complete the photocatalytic cycle (Equation (3)).

$$
\begin{gathered}
\text { g- } \mathrm{C}_{3} \mathrm{~N}_{4} \rightarrow \mathrm{e}^{-}+\mathrm{h}^{+} \\
\mathrm{CH}_{3} \mathrm{CH}_{2} \mathrm{OH}+2 \mathrm{~h}^{+} \rightarrow \mathrm{CH}_{3} \mathrm{CHO}+2 \mathrm{H}^{+} \\
\mathrm{O}_{2}+2 \mathrm{H}^{+}+2 \mathrm{e}^{-} \rightarrow \mathrm{H}_{2} \mathrm{O}_{2}
\end{gathered}
$$




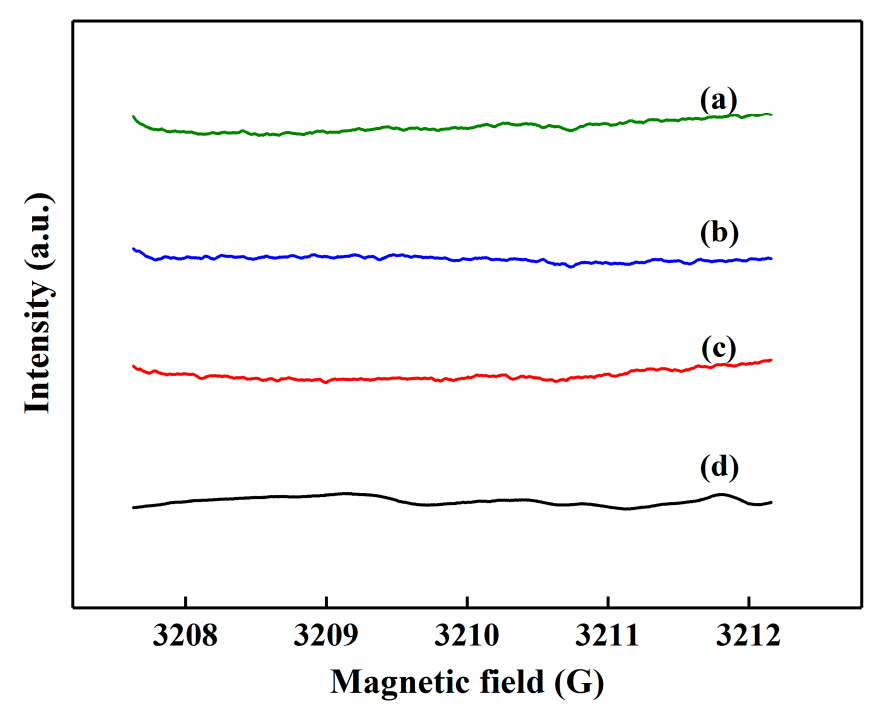

Figure 8. In situ electron spin resonance (ESR) spectra of photocatalytic ORR over different photocatalysts under visible light irradiation. Photocatalysts: (a) $\mathrm{CN},(\mathbf{b}) \beta-\mathrm{CD}-\mathrm{CN}$, (c) $0.05 \% \mathrm{Au} / \beta-\mathrm{CD}-\mathrm{CN}$, (d) $0.05 \% \mathrm{Pt} / \beta-\mathrm{CD}-\mathrm{CN}$.

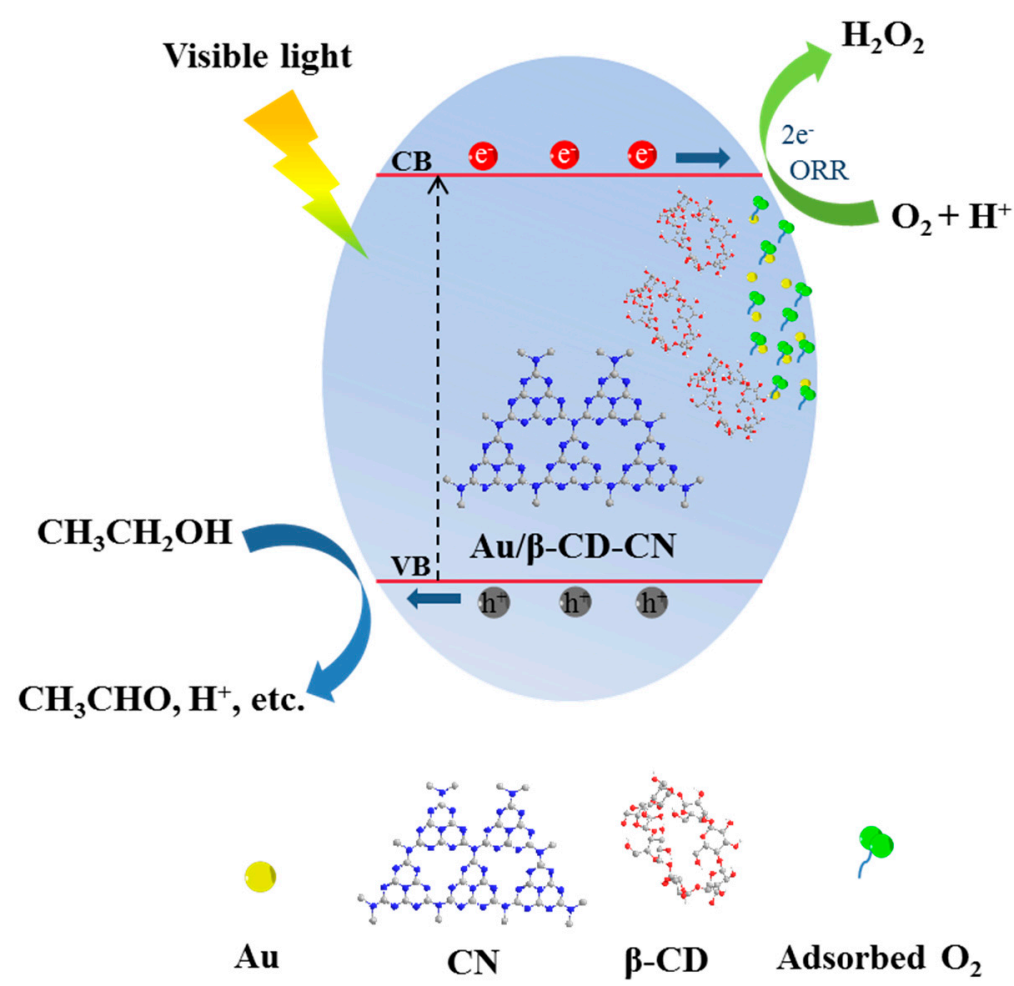

Figure 9. Proposed mechanism of photocatalytic $\mathrm{H}_{2} \mathrm{O}_{2}$ production over $\mathrm{Au} / \beta-\mathrm{CD}-\mathrm{CN}$ composite under visible light.

\section{Conclusions}

$\mathrm{Au} / \beta$-CD-CN was successfully obtained for improving photocatalytic activity for $\mathrm{H}_{2} \mathrm{O}_{2}$ production under visible light. The $\beta$-CD modified $\mathrm{CN}$ showed a hydrophobic property, which was beneficial for adsorption with oxygen to improve $\mathrm{H}_{2} \mathrm{O}_{2}$ production. Significantly, the optimal photocatalyst with the $\mathrm{Au}$ loading amount as low as $0.05 \%$ reached the maximal $\mathrm{H}_{2} \mathrm{O}_{2}$ production rate. Simultaneously, $\mathrm{Au} / \beta-\mathrm{CD}-\mathrm{CN}$ exhibited an inertness decomposition rate of $\mathrm{H}_{2} \mathrm{O}_{2}$ under visible light. The ESR test demonstrated that $\mathrm{H}_{2} \mathrm{O}_{2}$ was directly formed via 2-electron oxygen reduction over photocatalysis. 
This article provides a new method that loading $\mathrm{Au}$ on $\beta$-CD-modified $\mathrm{CN}$ can increase the adsorption and activation of $\mathrm{O}_{2}$ to improve photocatalytic activity for $\mathrm{H}_{2} \mathrm{O}_{2}$ production.

Supplementary Materials: The following are available online at http://www.mdpi.com/2079-4991/10/10/1969/s1: Table S1: Inductively coupled plasma mass spectrometry (ICP-MS) test results of $\mathrm{Au} / \beta-\mathrm{CD}-\mathrm{CN}$ with different $\mathrm{Au}$ content, Figure S1: Standard curve: a linear relationship for the optical absorbance at $454 \mathrm{~nm}$ as a function of $\mathrm{H}_{2} \mathrm{O}_{2}$ concentration.

Author Contributions: G.Z., Y.Z. and S.L. contributed equally to this work. They carried out the experimental work and prepared the manuscript. Z.G., Q.Z., G.S., L.F., L.L., W.L., and N.Z. provided useful assistance to this work. The corresponding author X.M. designed the experiment and prepared the manuscript. V.A.L.R. supervised this work and provided useful suggestions. All authors have read and agreed to the published version of the manuscript.

Funding: This work was supported by the National Natural Science Foundation of China (51872091), "Hundred Talents Program" of Hebei Province (E2018050013), Natural Science Foundation of Hebei Province (B2018209267), Outstanding Youth Funds of North China University of Science and Technology (JP201604 and JQ201706), and the Hong Kong Scholars Program.

Conflicts of Interest: The authors declare no conflict of interest.

\section{References}

1. Yusuke, Y.; Akifumi, N.; Takamitsu, M.; Kei, O.; Shunichi, F. Acetate induced enhancement of photocatalytic hydrogen peroxide production from oxalic acid and dioxygen. J. Phys. Chem. A 2013, 117, 3751-3760.

2. Lee, K.P.; Gopalan, A.I.; Komathi, S. Direct electrochemistry of cytochrome c and biosensing for hydrogen peroxide on polyaniline grafted multi-walled carbon nanotube electrode. Sens. Actuators B Chem. 2009, 141, 518-525. [CrossRef]

3. Gopalan, A.I.; Komathi, S.; Anand, G.S.; Lee, K.P. Nanodiamond based sponges with entrapped enzyme: A novel electrochemical probe for hydrogen peroxide. Biosens. Bioelectron. 2013, 46, 136-141. [CrossRef] [PubMed]

4. Komathi, S.; Gopalan, A.I.; Kim, S.K.; Anand, G.S.; Lee, K.P. Fabrication of horseradish peroxidase immobilized poly(N-[3-(trimethoxy silyl)propyl]aniline) gold nanorods film modified electrode and electrochemical hydrogen peroxide sensing. Electrochim. Acta 2013, 92, 71-78. [CrossRef]

5. Bui, Q.T.; Yu, I.K.; Gopalan, A.L.; Saianand, G.; Kim, W.; Choi, S.H. Facile Fabrication of Metal Oxide Based Catalytic Electrodes by AC Plasma Deposition and Electrochemical Detection of Hydrogen Peroxide. Catalysts 2019, 9, 888. [CrossRef]

6. Moon, G.H.; Kim, W.; Bokare, A.D.; Sung, N.E.; Choi, W. Solar production of $\mathrm{H}_{2} \mathrm{O}_{2}$ on reduced graphene oxide- $\mathrm{TiO}_{2}$ hybrid photocatalysts consisting of earth-abundant elements only. Energy Environ. Sci. 2014, 7, 4023-4028. [CrossRef]

7. Zuo, G.F.; Li, B.D.; Guo, Z.L.; Wang, L.; Yang, F.; Hou, W.S.; Zhang, S.T.; Zong, P.X.; Liu, S.S.; Meng, X.G.; et al. Efficient Photocatalytic Hydrogen Peroxide Production over $\mathrm{TiO}_{2}$ Passivated by $\mathrm{SnO}_{2}$. Catalysts 2019, 9, 623. [CrossRef]

8. Miwako, T.; Shin-Ichi, N.; Hiroaki, T. In situ liquid phase synthesis of hydrogen peroxide from molecular oxygen using gold nanoparticle-loaded titanium(IV) dioxide photocatalyst. J. Am. Chem. Soc. 2010, $132,7850-7851$.

9. Meng, X.G.; Zong, P.X.; Wang, L.; Yang, F.; Hou, W.S.; Zhang, S.T.; Li, B.D.; Guo, Z.L.; Liu, S.S.; Zuo, G.F.; et al. Au-nanoparticle-supported $\mathrm{ZnO}$ as highly efficient photocatalyst for $\mathrm{H}_{2} \mathrm{O}_{2}$ production. Catal. Commun . 2020, 134, 105860. [CrossRef]

10. Domènech, X.; Ayllón, J.A.; Peral, J. $\mathrm{H}_{2} \mathrm{O}_{2}$ Formation from photocatalytic processes at the $\mathrm{ZnO} /$ water interface. Environ. Sci. Pollut. R. 2001, 8, 285-287. [CrossRef]

11. Chen, S.H.; Jiang, Y.S.; Lin, H.Y. Easy Synthesis of $\mathrm{BiVO}_{4}$ for Photocatalytic Overall Water Splitting. ACS Omega 2020, 5, 8927-8933. [CrossRef] [PubMed]

12. Hirakawa, H.; Shiota, S.; Shiraishi, Y.; Sakamoto, H.; Hirai, T. Au Nanoparticles Supported on BiVO : $^{2}$ Effective Inorganic Photocatalysts for $\mathrm{H}_{2} \mathrm{O}_{2}$ Production from Water and $\mathrm{O}_{2}$ under Visible Light. ACS Catal. 2016, 6, 4976-4982. [CrossRef]

13. Yang, L.; Dong, G.; Jacobs, D.L.; Wang, Y.; Zang, L.; Wang, C. Two-channel photocatalytic production of $\mathrm{H}_{2} \mathrm{O}_{2}$ over g- $\mathrm{C}_{3} \mathrm{~N}_{4}$ nanosheets modified with perylene imides. J. Catal. 2017, 352, 274-281. [CrossRef] 
14. Peng, Y.L.; Wang, L.Z.; Liu, Y.D.; Chen, H.J.; Lei, J.Y.; Zhang, J.L. Visible-light-driven photocatalytic $\mathrm{H}_{2} \mathrm{O}_{2}$ production on $\mathrm{g}^{-} \mathrm{C}_{3} \mathrm{~N}_{4}$ loaded with $\mathrm{CoP}$ as a noble metal free cocatalyst. Eur. J. Inorg. Chem. 2017, 2017, 4797-4802. [CrossRef]

15. Xiong, W.; Huang, F.; Zhang, R.Q. Recent developments on carbon nitride based films for photoelectrochemical water splitting. Sustain. Energy Fuels 2020, 4, 485-503. [CrossRef]

16. Wu, C.B.; Yu, G.H.; Yin, Y.; Wang, Y.Z.; Chen, L.; Han, Q.; Tang, J.W.; Wang, B. Mesoporous Polymeric Cyanamide-Triazole-Heptazine Photocatalysts for Highly-Efficient Water Splitting. Small 2020, 16, 2003162. [CrossRef]

17. Chi, H.L.; Liu, J.X.; Zhang, X.Y.; Xue, X.G.; Zhang, D.D.; Lin, X.C.; Huang, P.R.; Sun, L.X.; Xiong, J.; Cai, P.; et al. Synergetic defects boost charge separation in $\mathrm{CN}$ for enhanced photocatalytic water splitting. J. Mater. Chem. C 2020, 8, 9366-9372. [CrossRef]

18. Maeda, K.; Wang, X.; Nishihara, Y. Photocatalytic Activities of Graphitic Carbon Nitride Powder for Water Reduction and Oxidation under Visible Light. J. Phys. Chem. C 2009, 113, 4940-4947. [CrossRef]

19. Meng, X.G.; Liu, L.Q.; Ouyang, S.X.; Xu, H.; Wang, D.F.; Zhao, N.Q.; Ye, J.H. Nanometals for Solar-to-Chemical Energy Conversion: From Semiconductor-Based Photocatalysis to Plasmon-Mediated Photocatalysis and Photo-Thermocatalysis. Adv. Mater. 2016, 28, 6781-6803. [CrossRef]

20. Samanta, S.; Martha, S.; Parida, K. Facile Synthesis of $\mathrm{Au} / \mathrm{g}-\mathrm{C}_{3} \mathrm{~N}_{4}$ Nanocomposites: An Inorganic/Organic Hybrid Plasmonic Photocatalyst with Enhanced Hydrogen Gas Evolution Under Visible-Light Irradiation. ChemCatChem 2014, 6, 1453-1462.

21. Zuo, G.F.; Liu, S.S.; Wang, L.; Song, H.; Zong, P.X.; Hou, W.S.; Li, B.D.; Guo, Z.L.; Meng, X.G.; Du, Y.; et al. Finely dispersed Au nanoparticles on graphitic carbon nitride as highly active photocatalyst for hydrogen peroxide production. Catal. Commun. 2019, 123, 69-72. [CrossRef]

22. Liu, G.G.; Zhao, G.X.; Wei, Z.; Liu, Y.Y.; Hong, P.; Zhang, H.B.; Dong, H.; Meng, X.G.; Peng, L.; Kako, T.; et al. In Situ Bond Modulation of Graphitic Carbon Nitride to Construct p-n Homojunctions for Enhanced Photocatalytic Hydrogen Production. Adv. Funct. Mater. 2016, 26, 6822-6829. [CrossRef]

23. Kosaka, K.; Yamada, H.; Matsui, S.; Echigo, S.; Shishida, K. Comparison among the Methods for Hydrogen Peroxide Measurements To Evaluate Advanced Oxidation Processes: Application of a Spectrophotometric Method Using Copper(II) Ion and 2,9-Dimethyl-1,10-phenanthroline. Environ. Sci. Technol. 1998, 32, 3821-3824. [CrossRef]

24. Jirkovsky, J.S.; Itai, P.; Elisabet, A.; Matej, H.; Simon, R.; Schiffrin, D.J. Single atom hot-spots at Au-Pd nanoalloys for electrocatalytic $\mathrm{H}_{2} \mathrm{O}_{2}$ production. J. Am. Chem. Soc. 2011, 133, 19432. [CrossRef]

25. Samira, S.; Arnau, V.C.; Mohammadreza, K.; Davide, D.; Paolo, M.; Björn, W.; María, E.E.; Paoli, E.A.; Rasmus, F.; Hansen, T.W. Enabling direct $\mathrm{H}_{2} \mathrm{O}_{2}$ production through rational electrocatalyst design. Nat. Mater. 2013, 12, 1137-1143.

26. Liu, S.S.; Dong, W.; Zeng, X.F.; Guo, Z.L.; Zong, P.X.; Li, B.D.; Meng, X.G.; Zuo, G.F. $\beta$-cyclodextrin modified g- $\mathrm{C}_{3} \mathrm{~N}_{4}$ nanosheet: A fluorescent drug carrier with ultrahigh drug loading capacity and $\mathrm{pH}$-responsive release. J. Chem. Technol. Biot. 2019, 94, 628-633. [CrossRef]

27. Salimi, A.; Yousefi, A.A. Analysis Method: FTIR studies of $\beta$-phase crystal formation in stretched PVDF films. Polym. Test. 2003, 22, 699-704. [CrossRef]

28. Song, W.C.; Hu, J.; Zhao, Y.; Shao, D.D.; Li, J.X. Efficient removal of cobalt from aqueous solution using $\beta$-cyclodextrin modified graphene oxide. RSC Adv. 2013, 3, 9514-9521. [CrossRef]

29. Banerjee, S.S.; Chen, D.H. Cyclodextrin conjugated magnetic colloidal nanoparticles as a nanocarrier for targeted anticancer drug delivery. Nanotechnology 2008, 19, 265602. [CrossRef]

30. Xu, X.Y.; Shang, H.; Zhang, T.Y.; Shu, P.J.; Liu, Y.P.; Xie, J.; Zhang, D.Y.; Tan, H.; Li, J.S. A stimuli-responsive insulin delivery system based on reversible phenylboronate modified cyclodextrin with glucose triggered host-guest interaction. Int. J. Pharm. 2018, 548, 649-658. [CrossRef]

31. Ge, L. Synthesis and photocatalytic performance of novel metal-free $\mathrm{g}-\mathrm{C}_{3} \mathrm{~N}_{4}$ photocatalysts. Mater. Lett. 2011, 65, 2652-2654. [CrossRef]

32. Gopalan, S.A.; Gopalan, A.I.; Vinu, A.; Lee, K.P.; Kang, S.W. A new optical-electrical integrated buffer layer design based on gold nanoparticles tethered thiol containing sulfonated polyaniline towards enhancement of solar cell performance. Sol. Energy Mat. Sol. Cells 2018, 174, 112-123. [CrossRef] 
33. Anand, G.S.; Gopalan, A.I.; Kang, S.W.; Lee, K.P. Development of a surface plasmon assisted label-free calorimetric method for sensitive detection of mercury based on functionalized gold nanorods. J. Anal. Atom. Spectrom. 2013, 28, 488-498. [CrossRef]

34. Lin, L.; Ou, H.H.; Zhang, Y.; Wang, X. Tri-s-triazine-based Crystalline Graphitic Carbon Nitrides for Highly Efficient Hydrogen Evolution Photocatalysis. ACS Catal. 2016, 6, 3921-3931. [CrossRef]

35. Tahir, M.; Amin, N.S. Photocatalytic reduction of carbon dioxide with water vapors over montmorillonite modified $\mathrm{TiO}_{2}$ nanocomposites. Appl. Catal. B-Environ. 2013, 142, 512-522. [CrossRef]

36. Liu, Z.; Hou, W.; Pavaskar, P.; Aykol, M.; Cronin, S.B. Plasmon resonant enhancement of photocatalytic water splitting under visible illumination. Nano Lett. 2011, 11, 1111-1116. [CrossRef]

37. Feng, D.X.; Nguyen, A.V.; Tong, X. Effect of contact angle and contact angle hysteresis on the floatability of spheres at the air-water interface. Adv. Colloid Interface Sci. 2017, 248, 69-84. [CrossRef]

38. Kuriki, R.; Matsunaga, H.; Nakashima, T.; Wada, K.; Yamakata, A.; Ishitani, O.; Maeda, K. Nature-Inspired, Highly Durable $\mathrm{CO}_{2}$ Reduction System Consisting of a Binuclear Ruthenium(II) Complex and an Organic Semiconductor Using Visible Light. J. Am. Chem. Soc. 2016, 138, 5159-5170. [CrossRef]

39. Balbuena, P.B.; Calvo, S.R.; Lamas, E.J.; Salazar, P.F.; Seminario, J.M. Adsorption and Dissociation of $\mathrm{H}_{2} \mathrm{O}_{2}$ on Pt and Pt-Alloy Clusters and Surfaces. J. Phys. Chem. B 2006, 110, 17452-17459. [CrossRef]

40. Shiraishi, Y.; Kanazawa, S.; Sugano, Y.; Tsukamoto, D.; Sakamoto, H.; Ichikawa, S.; Hirai, T. Highly Selective Production of Hydrogen Peroxide on Graphitic Carbon Nitride $\left(\mathrm{g}-\mathrm{C}_{3} \mathrm{~N}_{4}\right)$ Photocatalyst Activated by Visible Light. ACS Catal. 2014, 4, 774-780. [CrossRef]

(C) 2020 by the authors. Licensee MDPI, Basel, Switzerland. This article is an open access article distributed under the terms and conditions of the Creative Commons Attribution (CC BY) license (http://creativecommons.org/licenses/by/4.0/). 